\title{
Rombo syndrome
}

INSERM

\section{Source}

INSERM. (1999). Orphanet: an online rare disease and orphan drug data base. Rombo syndrome. ORPHA:3110

Rombo syndrome is characterized by vermiculate atrophoderma, milia, hypotrichosis, trichoepitheliomas, peripheral vasodilation with cyanosis and basal cell carcinomas. 